Rakenteiden Mekaniikka

Vol. 50, Nro 1, 2017, s. 25-40

http://rakenteidenmekaniikka.journal.fi/index

https:/doi.org/10.23998/rm.63497

(C) Kirjoittajat 2017.

Vapaasti saatavilla CC BY-SA 4.0 lisensoitu.

\title{
Teknologiset tekijät teräksen väsymisessä
}

\author{
Matti Makkonen
}

Tiivistelmä. Koneenelimien valmistusprosessi muuttaa aina kyseisen osan väsymisominaisuuksia. Näistä teknologisista tekijöistä käsitellään tässä kirjoituksessa seuraavia: materiaalivirheet, ainespaksuus ja pinnankarheus. Analyysi tuo esille, että väsymismitoituksen perusteena olevat kokeet tulisi aina tehdä koesauvoilla, jotka vastaavat väsymisominaisuuksiltaan mitoituskohdetta. Joitakin suunnitteluohjeita annetaan tapauksille, joissa tämä ei ole mahdollista. Päähuomio kiinnitetään pinnankarheuteen. Artikkelissa osoitetaan, että pinnan karheus on mahdollista ottaa huomioon tarkemmin käyttäen tilastollisia menetelmiä. Kuitenkin ainoa tilastollinen mitoitusmenetelmä, joka tukee tällaista menettelyä, on kirjoittajan kehittämä, ydintyneiden alkusäröjen jakaumaan perustuva menetelmä. Pintanaarmujen syvyys voidaan yhdistää alkuvikoihin tilastollisesti. Saatua kokonaissärösyvyyttä voidaan käyttää väsymislujuuden arviointiin soveltamalla murtumismekaniikkaa.

Avainsanat: väsyminen, koon vaikutus, pinnankarheus, väsymissärön ydintyminen, väsymiskoetulosten siirrettävyys

Vastaanotettu 21.1.2016. Hyväksytty 21.4.2017. Julkaistu verkossa 19.5.2017.

\section{Johdanto}

Todellisten koneenosien väsymislujuutta arvioitaessa on otettava huomioon erilaiset teknologiset tekijät. Nämä tekijät ovat seurausta osan valmistusprosessista. Tekijöihin kuuluvat muun muassa seuraavat: vaihteleva mikrorakenne, erityisesti raekoko, sulkeumien ja muiden materiaalivirheiden määrä ja koko, rakeiden ja sulkeumien muoto ja suuntautuminen muokkauksen takia (kuuma- ja kylmämuokkaus ja vastaavat), valmistusprosessin aiheuttamat jäännösjännitykset (valu, kuuma- ja kylmämuokkaus ym.), pinnankarheus, materiaalin staattinen lujuus.

Nämä tekijät eivät ole riippumattomia, vaan ne vaikuttavat toisiinsa. Tekijöillä on aina vaikutus kappaleen väsymisominaisuuksiin, sekä väsymislujuuden keskiarvoon että hajontaan. Mitoituksessa tilanteen tekee vaikeaksi se, että käytettävissä olevat väsymiskoetulokset eivät useinkaan täysin vastaa kohdekappaletta.

Materiaalinpaksuuden muutos vaikuttaa useisiin edellä mainittuihin tekijöihin. Siksi sitä käsitellään kirjoituksessa erikseen. 


\section{Aiemmat tutkimukset}

Tämän kirjoituksen aihe kuuluu väsymislujuuden kokeellisten tulosten siirrettävyyteen. Kyseisessä aihepiirissä aiemmin tehdyt tutkimukset keskittyvät lähinnä koon vaikutukseen väsymisessä. Tätä ei käsitellä tässä artikkelissa. Kirjoittajan väitöskirjassa [1] on laajahko katsaus koon vaikutuksen eri arviointimenetelmiin.

Koetulosten siirrettävyyttä käsitellään muun muassa kirjoituksissa [2] - [4]. Näissä kaikissa koon vaikutusta lähestytään korkean jännityksen alaisen tilavuuden periaatteella. Näiden tutkimusten koejärjestelyissä on pyritty eliminoimaan tässä kirjoituksessa käsiteltyjä teknologisia vaikutuksia. Esimerkiksi artikkelissa [4] referenssikokeiden koesauvat on irrotettu tarkastelun kohteena olevista laippa-akseleista kriittisen kohdan läheisyydestä. Koon vaikutuksen arviointiin on artikkelissa käytetty Kuguelin ehdottamaa korkean jännityksen alaisen tilavuuden menetelmää. Tätä sovelletaan lähteessä [3] esitetyllä periaatteella. Siinä koon vaikutus on muunnettu kokeellisesti hajontanauhafunktioksi, josta koon vaikutuksen voi lukea yksinkertaisesti. Menetelmän väitetään ottavan huomioon myös geometrisen koon vaikutuksen eli jännitysgradientin merkityksen. Kuguelin menetelmää on kirjoittaja arvioinut lähteessä [1], samoin kuin jännitysgradientin tarkempaa huomioimista.

Pinnanlaadun vaikutuksesta löytyy suuri määrä tutkimuksia. ESDU:n suunnittelukäyrästö [5] perustuu suureen joukkoon tällaisia. ESDU:n käyrästössä on esitetty pinnanlaadun korjauskerroin pinnankarheuden $R$ funktiona, parametrina teräksen murtoraja. Kirjoituksessa [6] esitetään hiukan erilainen lähestymistapa. Siinä on johdettu väsymiseliniälle lauseke

$$
N_{f}=C\left(\frac{\sigma_{T S}-\sigma_{\max }}{\sigma_{a}-\sigma_{w}}\right)^{n}
$$

jossa $\sigma_{T S}$ on materiaalin murtoraja, $\sigma_{\max }$ suurin jännitys syklissä, $\sigma_{a}$ jännitysamplitudi ja $\sigma_{w}$ materiaalin väsymisraja. $C$ ja $n$ ovat vakioita, jotka saadaan sovittamalla kiillotetun koesauvan väsymistuloksiin. Väsymisraja lasketaan jännitysintensiteetin lausekkeen (7) avulla käyttämällä alkusärökokona arvoa

$$
a_{e q}=10 R_{a}+a_{i}
$$

jossa $R_{a}$ on pinnankarheuden keskiarvo ja $a_{i}$ kiillotetun koesauvan perusteella määritetty alkusärökoko. Kirjoittaja toteaa perustelematta, että tyypillinen pintanaarmun syvyys on noin $10 R_{a}$. Kaava (1) yhdistää siis ydintyvän alkusärön ja pinnankarheuden, mutta ei huomioi millään lailla kappaleen kokoa eikä muotoa.

Artikkelissa [7] kirjoittajien pyrkimyksenä on löytää pinnankarheudelle lovenmuotoluku perinteistä väsymismitoitusta varten. He esittävät pinnankarheudelle tehollisen lovenmuotoluvun kaavaa

$$
K_{t}^{\prime}=1+n\left(\frac{R_{a}}{\rho^{\prime}}\right)\left(\frac{R_{y}}{R_{z}}\right),
$$

jossa $R_{a}, R_{y}$ ja $R_{z}$ ovat perinteiset pinnankarheuden tunnusluvut ja $\rho^{\prime}$ on pintanaarmujen pohjien tehollinen säde. Vakio $n$ saa arvon 1 leikkausjännitykselle ja 2 
vetojännitykselle. Väsymislujuus lasketaan sen jälkeen määrittämällä lovenvaikutusluku loviherkkyyden avulla. Edellä mainittujen ongelmien lisäksi menetelmään sisältyvät siten perinteisen mitoitustavan tunnetut heikkoudet.

Materiaalivirheisiin perustuvista menetelmistä voidaan ottaa esille Murakamin [8] kehittämä menetelmä, koska se on ehkä eniten huomiota saanut lajissaan. Se perustuu vikakokojen jakaumien tilastolliseen käsittelyyn. Suurimman vikakoon estimaatti muunnetaan kokemusperäisen kaavan avulla väsymislujuuden ennusteeksi. Tästä menetelmästä on joitakin huomioita seuraavassa luvussa.

\section{Materiaalivirheet ja mikrorakenne}

Kirjoituksessa [9] Goto and Nisikani ovat tutkineet hiiliteräksen väsymissäröjen ydintymiskohtia. Jännitystason ollessa lähellä väsymisrajaa 75 prosenttia säröistä ydintyi sulkeumien kohdalle. Prosenttiluku aleni jonkin verran jännitysheilahduksen kasvaessa. Loput säröistä ydintyivät liukunauhoihin. Koska enemmistö säröistä ydintyy materiaalivikoihin, on perusteltua olettaa, että väsymislujuuden ja ainevikajakauman kesken vallitsee korrelaatio. Murakamin [8] menetelmän lähtökohta onkin juuri tämä.

Muutamia vuosia sitten Suomessa toteutettiin laaja tutkimusohjelma nimeltä FateDefex (Clean steels and fatigue survival with material imperfections). Kokeelliset tulokset on julkaistu mm. Roikon diplomityössä [10]. Tulosten arviointi suoritettiin Murakami-Endon tilastollisella mallilla [11]. Saaduissa tuloksissa on suurta hajontaa eikä korrelaatio kokeellisiin tuloksiin eräissä koesarjoissa ole tyydyttävä, ks. taulukko 1.

Terästen raekoko tulisi pitää mahdollisimman pienenä, koska sillä on edullinen vaikutus sekä lujuuteen että sitkeyteen. Rakeiden koko ja muoto kuitenkin vaihtelevat suuresti riippuen kappaleen koosta, muodosta ja prosessoinnista. Isossa osassa jäähtymisnopeus kuumavalssauksen tai muun käsittelyn jälkeen on hitaampi ja johtaa karkeampaan mikrorakenteeseen. Jopa saman kappaleen pinnassa ja keskustassa saattaa raekoossa olla suuri ero.

Fate-Defex projektin yhdessä koejärjestelyssä tutkittiin rakeiden ja sulkeumien muodon vaikutusta. Tarkoituksena kokeessa oli selvittää kuumavalssauksen vaikutus väsymisominaisuuksiin levyn kahdessa kohtisuorassa suunnassa. Koekappaleet irrotettiin suuresta paperikoneen telasta. Toinen koesarja valmistettiin telan pituussuunnassa, toinen poikittaisessa suunnassa. Saadut kokeelliset tulokset $\Delta \sigma_{\text {R,exp }}$ sekä lasketut ennusteet $\Delta \sigma_{\mathrm{R}, \text { calc }}$ näkyvät taulukossa 1 .

Taulukko1. Kokeellisia tuloksia ja saadut ennusteet Murakami-Endon mallilla [10]

\begin{tabular}{lll}
\hline Koesarja & $\Delta \sigma_{\mathrm{R}, \exp }[\mathrm{MPa}]$ & $\Delta \sigma_{\mathrm{R}, \text { calc }}[\mathrm{MPa}]$ \\
\hline Axial-FS & 463 & 298 \\
Tangential-FS & 370 & 286 \\
\hline
\end{tabular}

Nähdään selvästi, että Murakami-Endon menetelmä ei anna tässä tapauksessa tyydyttäviä tuloksia. Koska malli perustuu sulkeumakokojen arviointiin, voisi odottaa, että edes ennusteiden suhde kohtisuorissa suunnissa olisi lähellä oikeaa. Sulkeumien muoto ja poikkileikkaushan muuttuu valssauksen aikana eri suunnissa erilaiseksi. 
Kuitenkin väsymislujuuksien suhde kokeissa oli 1,25, kun laskettujen arvojen suhde on 1,04 .

Ero tulosten hajonnassa oli paljon suurempi kuin keskiarvoissa. Nämä molemmat tarvitaan tarkkojen väsymislujuuden ennusteiden saamiseksi. Näyttää siltä, että ei ole mallia tai teoriaa, joka antaisi aina tarkan ennusteen materiaalivirheiden vaikutukselle väsymislujuuden tilastolliseen käyttäytymiseen. Ainoa tapa on silloin tehdä väsymiskokeet koesauvoilla, joiden tilastollinen edustavuus on hyvä, toisin sanoen sauvoilla, joiden voidaan katsoa kuuluvan samaan emopopulaatioon.

\section{Materiaalipaksuus}

Kuten edellä todettiin, materiaalipaksuus käsitellään omana aihepiirinään, koska sillä on vaikutus useimpiin luvussa 1 esitettyihin tekijöihin.

\section{Väsymislujuuden keskiarvo}

Materiaalipaksuudella on pari mielenkiintoista vaikutusta väsymismitoitukseen. On hyvin tunnettua, että suurempi ainespaksuus johtaa alempaan staattiseen lujuuteen. Se johtuu ennen muuta siitä, että jäähtymisnopeus kuumavalssauksen tai valun jälkeen on paksummassa kappaleessa hitaampi, mikä johtaa suurempaan raekokoon. Raekoon kasvu taas alentaa teräksen lujuutta.

Laajan kokeellisen aineiston perusteella Buch on osoittanut, että murtolujuuden $f_{u}$ ja taivutusväsymislujuuden $\Delta \sigma_{\mathrm{R}, \mathrm{rb}}$ välillä on voimakas korrelaatio [12]. Matala- ja keskilujuuksisille teräksille Buch antaa kaavan

$$
\Delta \sigma_{R, r b}=0,454 f_{u}+8,4 \mathrm{MPa}
$$

Kaava antaa väsymisrajan 50\% todennäköisyydelle. Aivan ilmeisesti yhtälön voidaan katsoa olevan voimassa myös tapauksessa, jossa ainespaksuus alentaa staattista lujuutta. Materiaalipaksuuden vaikutus staattiseen lujuuteen on hyvin tunnettu ja voidaan joka tapauksessa määrittää yksinkertaisella vetokokeella. Näin ollen arvio väsymislujuuden keskiarvolle voidaan saada nopeasti esitetyn kaltaisesta kaavasta. Koska mainitun suoran sovitus osoittaa melko suurta hajontaa, väsymiskokeen suorittaminen on tietenkin suositeltavaa.

\section{Väsymislujuuden hajonta}

Magin on tutkinut erilaisia teknologisia koon vaikutuksia väitöskirjassaan [13]. Hänen koekappaleensa oli valmistettu nuorrutusteräksestä 30CrNiMo8. Erikokoisten koekappaleiden staattinen lujuus oli säädetty mahdollisimman tarkasti samaksi. Yhdessä koesarjassa koekappaleet oli valmistettu $23 \mathrm{~mm}$ halkaisijaisesta aihiosta. Samanlaiset sarjat valmistettiin $181 \mathrm{~mm}$ aihion pintaosasta (181 S), kolmas sarja aihion keskiosasta (181 M). Kokeissa saadut väsymisrajat $\Delta \sigma_{\mathrm{R} \text {,exp }}$ sekä niiden hajonta on esitetty taulukossa 2. 
Taulukko 2. Erikokoisista aihioista valmistettujen koesauvojen väsymislujuudet [13]

\begin{tabular}{lllll}
\hline Aihio & $f_{u}[\mathrm{MPa}]$ & $\begin{array}{l}\Delta \sigma_{\mathrm{R}, \exp } \\
{[\mathrm{MPa}]}\end{array}$ & $\begin{array}{l}\text { Keskihajonta } \\
{[\mathrm{MPa}]}\end{array}$ & $\Delta \sigma_{\mathrm{R}, \exp } / f_{u}$ \\
\hline 23 & 938 & 463 & 51 & 0,49 \\
$181 \mathrm{~S}$ & 912 & 491 & 108 & 0,54 \\
$181 \mathrm{M}$ & 904 & - & - & \\
181 Kaikki & 908 & 475 & - & 0,52 \\
\hline
\end{tabular}

Aihion $181 \mathrm{~mm}$ pintaosasta valmistettujen sauvojen hajonta oli yli kaksinkertainen $23 \mathrm{~mm}$ aihioon verrattuna. Keskiosasta valmistettujen sauvojen keskiarvoa ja hajontaa ei pystytty määrittämään. Tämä siksi, että kaksiporraskokeessa murtumien ja runout:ien määrä kokeen molemmilla jännitysheilahduksien arvoilla oli sama.

Mielenkiinnon vuoksi taulukkoon on laskettu keskiarvo kaikille $181 \mathrm{~mm}$ aihion kokeille. Saatu arvo osoittaa, että keskiosan koesauvojen väsymislujuuden keskiarvo täytyy olla alempi kuin mitattu staattinen lujuus antaa olettaa. Toisaalta pintaosan väsymislujuus on jonkin verran odotettua korkeampi. Magin ei ole yrittänyt selittää näitä eroja. Taulukon oikeanpuolimmaiseen sarakkeeseen on laskettu suhde $\Delta \sigma_{\mathrm{R}, \exp } / f_{u}$ Buchin kaavalla (4).

Kirjoittaja on analysoinut Maginin koetuloksia samoin kuin Böhmin väitöskirjan [14] tuloksia lähteessä [1]. Mainituissa töissä on käytetty samaa materiaalia: 30CrNiMo8. Koeohjelmat sisältävät erikokoisia sileitä sekä lovellisia sauvoja. Tilastollisesta koon vaikutuksesta johtuen väsymislujuuksissa on suuret erot. Kirjoittaja osoittaa, että alkusäröjakaumiin perustuvalla tilastollisella menetelmällä saadaan luotettavat ennusteet kaiken muotoisille ja -kokoisille kappaleille. Lisäksi koetulosten arvioinnissa kävi selväksi, että erikokoisista lähtöaihioista valmistettujen koesauvojen ei voida olettaa kuuluvan samaan emopopulaatioon. Vain samankokoisesta aihiosta valmistetut sauvat olivat suoraan verrattavissa keskenään. Kirjoittaja pystyi kuitenkin saamaan tarkkoja ennusteita myös erikokoisten aihioiden kesken, kunhan teknologinen hajonnan muutos näissä otettiin huomioon.

Maginin and Böhmin tulokset $\Delta \sigma_{\text {R,exp }}$ sileille sauvoille sekä lasketut estimaatit $\Delta \sigma_{\mathrm{R} \text {,calc }}$ on esitetty taulukossa 3 . Böhmin tulokset on merkitty symbolilla X. 
Taulukko 3. Sileiden sauvojen koetulokset ja kirjoittajan laskemat estimaatit [1, 15]

\begin{tabular}{ccccccc}
\hline $\begin{array}{c}\text { Koe- } \\
\text { sarja }\end{array}$ & $D$ & $\begin{array}{c}\Delta \sigma_{\mathrm{R}, \exp } \\
{[\mathrm{MPa}]}\end{array}$ & $\begin{array}{c}\Delta \sigma_{\mathrm{R}, \text { calc }} \\
{[\mathrm{MPa}]}\end{array}$ & $\begin{array}{c}S_{E} \\
\%\end{array}$ & $\begin{array}{c}S_{\exp } \\
\%\end{array}$ & $\begin{array}{c}S_{\exp }-S_{E} \\
\%\end{array}$ \\
\hline $\mathrm{X} 1$ & 7 & 937 & 937 & 4,8 & ref. & ref. \\
$\mathrm{X} 2$ & 20 & 800 & 844 & 6,1 & 7,1 & 1,0 \\
$\mathrm{X} 3$ & 38 & 777 & 777 & 6,7 & 8,4 & 1,7 \\
$7 / 1$ & 7 & 934 & 934 & 5,4 & 7,5 & 2.1 \\
$10 / 1$ & 10 & 876 & 897 & 5,1 & ref. & ref. \\
$20 / 1$ & 20 & 848 & 853 & 7,8 & 7,9 & 1,0 \\
$38 / 1$ & 38 & 746 & 735 & 8,4 & 10,6 & 2,2 \\
$80 / 1$ & 80 & 788 & 829 & 3.5 & 4,4 & 0,9 \\
\hline
\end{tabular}

Kappaleen koon kasvaessa sekä väsymislujuuden keskiarvo että hajonta alenevat. Tämä on helppo mieltää, kun tarkastellaan ketjuanalogiaa heikoimman lenkin teorian mukaan. Ajatellaan pitkällä ketjulla saatuja lujuuskokeen tuloksia. Jaetaan ketju sitten lyhyempiin pätkiin. Vain yhden lujuus on yhtä alhainen kuin pitkän ketjun. Hajonnan lyhyissä pätkissä taas täytyy muodostua paljon korkeammaksi.

Tässä yhteydessä koon on käsitettävä riippuvan tehollisesta jännityspinta-alasta [1, 14]. Kuitenkin taulukossa annetut hajonta-arvot kasvavat kappaleen halkaisijan suuretessa. Syy tähän täytyy olla teknologisissa vaikutuksissa. Kuten edellä selitettiin, todennäköinen syy on, että raekoko pyrkii kasvamaan jäähtymisnopeuden aletessa kuumavalssauksen jälkeen. Teoreettinen hajonta ääriarvoteorian mukaan on laskettu sarakkeeseen $s_{E}$, kokeellinen arvo on ilmoitettu sarakkeessa $S_{\text {exp }}$. Viimeinen sarake esittää näiden kahden erotuksen. Yksi arvo lisää saadaan Maginin tuloksista $181 \mathrm{~mm}$ aihiolle. Maginin tuloksista saatuihin $s_{\text {exp }}-s_{E}$-arvoihin sovitettiin trendikäyrä. Kuvassa 1 on esitetty saatu tulos. Böhmin tuloksista saadut arvot on myös merkitty kaavioon.

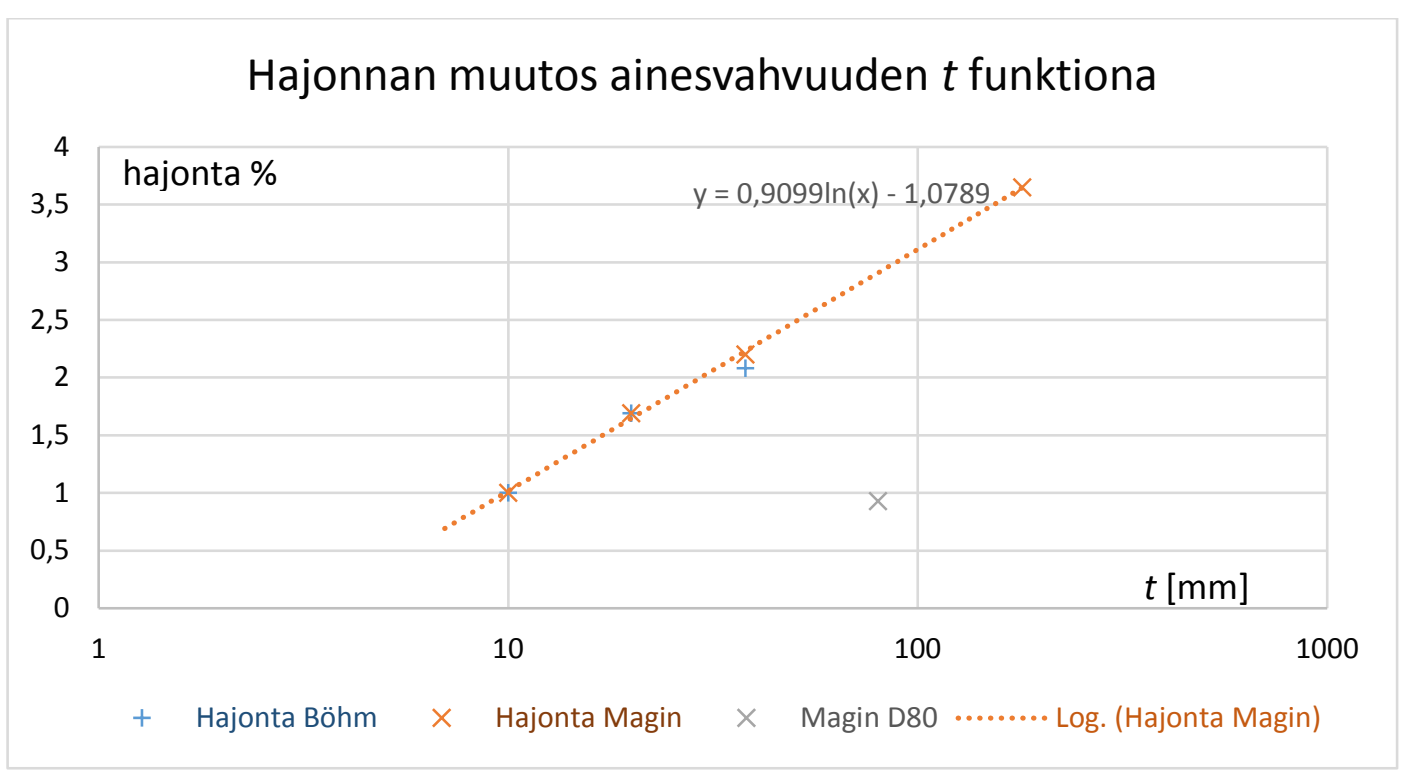

Kuva 1. Väsymisrajan hajonnan kasvu ainespaksuuden $t$ funktiona 
Teräksen 30CrNiMo8 ainespaksuuden $t$ muutoksesta johtuva variaatiokerroin $s$ prosentteina materiaalinpaksuuden funktiona voidaan siis määrittää kaavalla

$$
s(t)=0,91 t+1,08 \text {. }
$$

Aihio 80 mm jätettiin sovituksessa syrjään, koska sen arvo poikkeaa täysin muista. Taulukosta 3 voidaan nähdä, että sen väsymisarvot eivät ole linjassa muiden tulosten kanssa. Magin ei ole esittänyt väitöskirjassaan mahdollista syytä poikkeamaan.

\section{Johtopäätökset ainespaksuuden vaikutuksen analyysistä}

Tässä luvussa esitetystä analyysistä voidaan tehdä seuraavia johtopäätöksiä. Väsymislujuuden hajonta kasvaa ainespaksuuden vaikutuksesta logaritmisesti. Hajonnan kasvu voidaan määrittää tekemällä väsytyskokeet ei paksuisesta aihiosta valmistetuilla koesauvoilla. Teknologinen vaikutus saadaan helpoiten erotetuksi tilastollisesta koon vaikutuksesta käyttämällä kokeissa keskenään täsmälleen samanlaisia koesauvoja samaan tapaan kuin Maginin työssä 23 ja 181 mm aihioille.

\section{Pinnankarheus}

\section{Johdanto}

Valtaosassa tapauksia kriittinen alkusärö ydintyy kappaleen pintaan. Syitä tähän on käsitelty kirjoittajan väitöskirjassa [1]. Siinä osoitetaan, että todennäköisyys särön kasvun alkamiselle pinnan alta on äärimmäisen pieni kiillotetuissakin koesauvoissa jopa aksiaalisessa kuormituksessa. Todellisissa koneenosissa maksimijännitys esiintyy melkein aina osan pinnalla. Silloin pinnankarheus alentaa huomattavasti väsymislujuutta. Alan käsikirjoissa esitetäänkin aina pinnankarheuden korjauskerroin perustelematta asiaa tarkemmin.

Perinteisissä mitoitusmenetelmissä pinnankarheus otetaan huomioon kokemusperäisten suunnittelukäyrästöjen avulla. Käyrästöistä saadaan vähennyskerroin pinnankarheusarvon funktiona, parametrina materiaalin murtolujuus. ESDU on julkaissut yhden eniten käytetyistä käyrästöistä [5]: katso osakopio kuvassa 6. Käsikirjaesityksistä poiketen ESDUN käyrästöihin on merkitty useista tutkimusohjelmista saadut koepisteet. Käyrät on piirretty samanmuotoisina määrävälein eivätkä koepisteet satu piirretyille käyrille kovinkaan hyvin. Kun hajonta on vielä melko suurta, ei tämäkään käyrästö voi olla kovin tarkka.

Pinnankarheus on satunnaissuure ja tulisi siksi käsitellä tilastollisesti. Useita tilastollisia väsymismitoitusmenetelmiä on esitetty: Murakamin menetelmä on jo mainittu edellä. Heikoimman lenkin menetelmä on toinen yleisesti käytetty. Sen esitti ensimmäisenä Weibull [18]. Böhm on kehittänyt menetelmää edelleen viitteessä [14]. Kuitenkaan nämä menetelmät eivät anna mahdollisuutta lisätä pinnankarheuden vaikutusta tilastomatematiikan keinoin. Ainoa menetelmä, jossa tämä mahdollisuus on, tarjoutuu kirjoittajan laskentamallissa. Siksi sitä käsitellään seuraavassa. 


\section{Kirjoittajan menetelmä}

Kirjoittaja on kehittänyt tilastollisen väsymismitoitusmenetelmän viitteissä $[1,15,16$, 17]. Menetelmä perustuu ydintyneiden alkusäröjen jakaumaan. Alkusärö on satunnaismuuttuja, pinnankarheus on toinen. Siksi nämä kaksi on periaatteessa mahdollista yhdistää tilastomatemaattisesti.

Jos $a_{\mathrm{i}}$ on kriittinen särön syvyys ja $\Delta K_{\mathrm{I}, \mathrm{th}}$ jännitysintensiteettikertoimen kynnysarvo, yhteys näiden kahden välille saadaan lineaarielastisen murtumismekaniikan avulla. Jännitysintensiteettikertoimen lausekkeen avulla saadaan

$$
\Delta K_{\mathrm{I}, \mathrm{th}}=\beta \Delta \sigma \sqrt{\pi a_{\mathrm{i}}},
$$

jossa $\beta$ on geometriakerroin ja $\Delta \sigma$ jännitysvaihtelu.

Tästä voidaan ratkaista alkusärökoko

$$
a_{i}=\frac{1}{\pi}\left(\frac{\Delta K_{\mathrm{I}, \mathrm{th}}}{\beta \Delta \sigma}\right)^{2}
$$

Alkusäröjen jakauma väsyttävässä kuormituksessa ei yleensä ole tiedossa. Siksi on käytettävä epäsuoraa menettelyä, joka perustuu tavallisiin väsytyskokeisiin. Ideana on, että keskimääräinen alkusärökoko ja sen hajonta lasketaan kaavan (7) avulla. Jännitysheilahdukseksi $\Delta \sigma$ kaavaan sijoitetaan saatu väsymisraja. Säröjakaumaksi voidaan olettaa Weibull- tai lognormaalijakauma: jälkimmäistä sovelletaan tässä kirjoituksessa. Jakauman parametrit asetetaan siten, että estimaatit keskiarvolle ja hajonnalle tulevat samoiksi kuin väsytyskokeista saadut. Menettely on selostettu tarkemmin viitteissä [1] ja [15].

Pinnankarheuden jakauma voidaan määrittää mittauksin. Kun sekä alkusäröjen että pinnankarheuden jakaumat ovat selvillä, näiden yhteisjakauma (pdf) on [19]

$$
f_{a+R}(z)=\int_{-\infty}^{\infty} f_{a}(x) f_{R}(z-x) d x,
$$

jossa $f_{a}(x)$ on alkusäröjen tiheysjakauma ja $f_{R}(\mathrm{z}-x)$ pinnankarheuden tiheysjakauma.

Kappaleen väsymislujuuden määrää suurin sen pintaan ydintyvä mikrosärö. Sen estimaatti saadaan ääriarvoteorian avulla. Otoksen suurimman särön kertymäfunktio (cdf) on

$$
F_{a+R_{n: n}}(z)=F_{a+R}^{n}(z)
$$

ja tiheysfunktio (pdf)

$$
f_{a+R_{n: n}}(z)=n F_{a+R}^{n-1}(z) f(z)
$$

Ydintyneiden säröjen otoskokoa $n$ ei voida tarkasti tietää. Järkevä arvio on kymmenen säröä yhden neliömillimetrin alueella. Kuten viitteessä [1] osoitetaan, saatu odotusarvo ei ole herkkä virheelle tässä arviossa. 


\section{Pinnankarheuden mittaukset}

Pinnankarheuden tilastolliset ominaisuudet määritettiin hiiliteräksellä E470, mikä on yleinen koneistamalla valmistettujen koneenosien teräslaatu. Aihio oli pyörötanko, jonka halkaisija on $50 \mathrm{~mm}$. Kolme eri pinnankarheusarvoa toteutettiin muuttamalla syöttöä sorvauksessa.

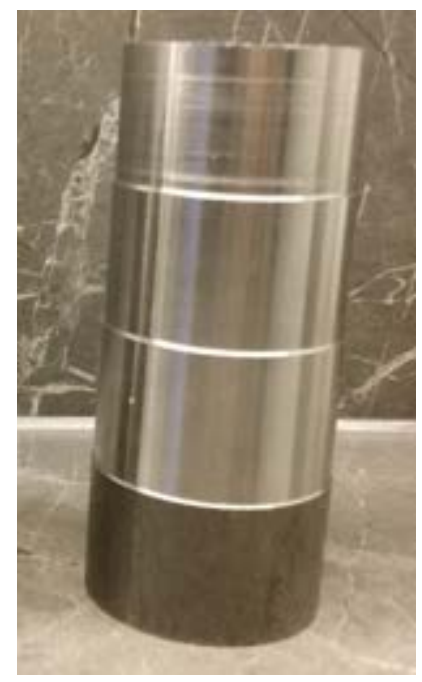

Kuva 2. Pinnankarheusmittausten koekappale.

Jokaisesta alueesta tehtiin 19 mittausta. Näytepituus oli 2,5 mm. Yhteenveto tuloksista on esitetty taulukossa 4 , jossa $R_{z}$ on huippu-laakso-etäisyys ja $R_{a}$ keskimääräinen karheuden poikkeama. Kuva 3 esittää erästä lyhyttä jaksoa yhdestä mittauksesta.

Taulukko 4. Pinnankarheusmittaukset.

\begin{tabular}{lccc}
\hline & Alue 1 & Alue 2 & Alue 3 \\
\hline syöttö $s \mu \mathrm{m}$ & 0,03 & 0,074 & 0,095 \\
keskiarvo $R_{a} \mu \mathrm{m}$ & 1,4 & 8,2 & 12,3 \\
keskimääräinen $R_{\mathrm{z}} \mu \mathrm{m}$ & 7,55 & 35,0 & 51,3 \\
standardipoikkeama $R_{\mathrm{z}} \mu \mathrm{m}$ & 1,18 & 1,67 & 1,55 \\
\hline
\end{tabular}




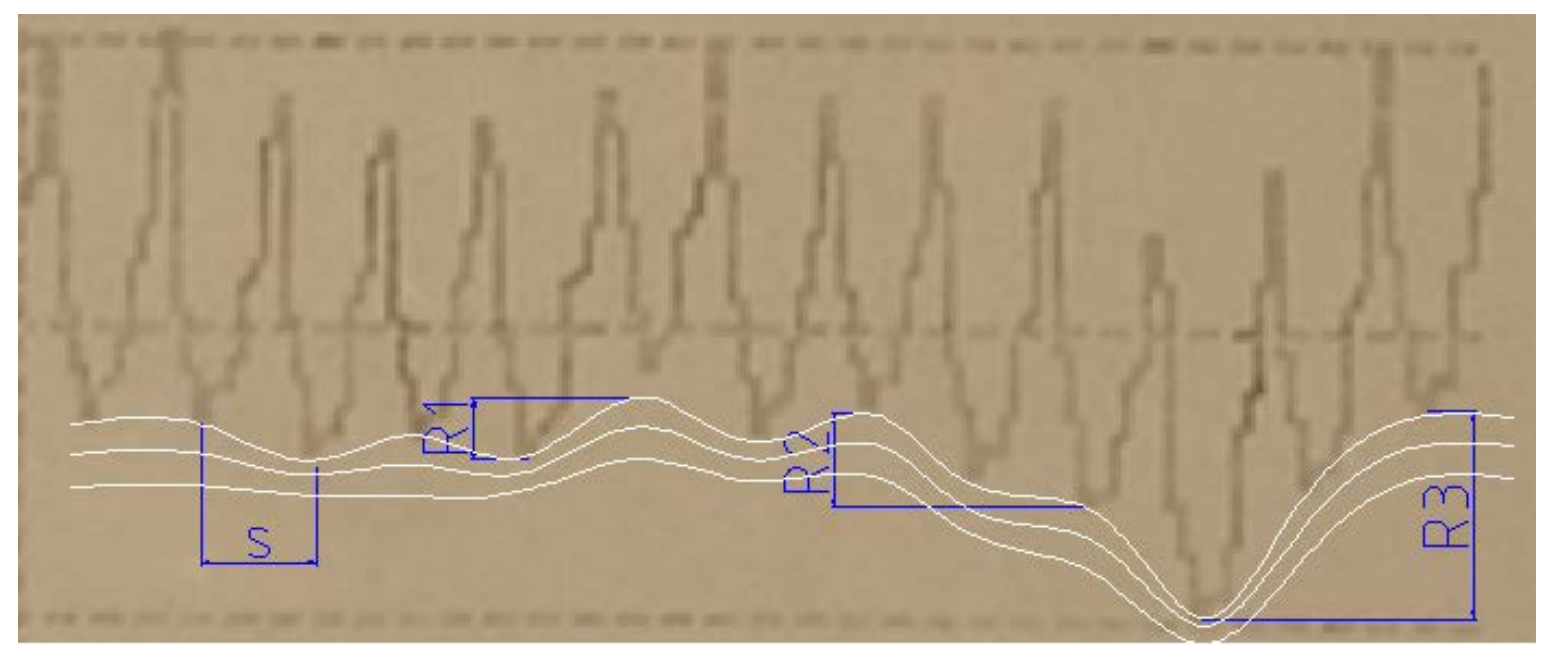

Kuva 3. Näyte pinnankarheusmittauksista.

Kuvasta 3 nähdään, että pinnankarheusarvojen mittausarvoihin liittyy useita käytännön ongelmia. Ensiksikin yksikään vakioiduista pinnankarheusparametreista ei sovellu väsymisanalyysiin. Vain laaksojen syvyydet ovat merkittäviä väsymisessä. Tämän havainnollistamiseksi kuvaan on piirretty kaaviollisia jännityksen tasaarvokäyriä. Nähdään, että laaksojen järjestys vaikuttaa niiden teholliseen syvyyteen. Kolme merkittyä arvoa R1, R2 and R3 tuovat esille tätä. Koska mitään aritmeettista tai tilastollista määrittelyä teholliselle syvyydelle ei ole löydettävissä, tässä kirjoituksessa valittiin suureelle likiarvo: $R=R_{z} / 3$.

Toinen ongelma on, että selvästikään pinnankarheus ei ole luonteeltaan täysin riippumaton satunnaismuuttuja. Naarmujen lukumäärä määräytyy syötön suuruudesta $s$. On myös selvää, että tangentiaalisuunnassa $R_{z}$-arvon suuruus ei ole riippumaton.

Tilastollisessa analyysissä tarvitaan tieto siitä, mitä otoskokoa saatu suurin pinnankarheus $R$ edustaa. Otoskoko tulisi määritellä pinta-alayksikköä kohti, mutta mittaus tehdään pitkin viivaa. Ongelmana on myös, että laakson syvyys on tuntemattomalla tavalla osittain jatkuva ulkokehää pitkin. Tässäkin joudutaan tekemään yksinkertaistava olettamus. Otoksen kooksi otetaan kymmenen kertaa naarmujen määrä mittauspituudella 2,5 mm. Otoskooksi alueilla 1, 2 and 3 saatiin silloin $n=833, n=338$ ja $n=263$.

Kaavan (7) mukaan väsymisraja muuttuu suhteessa särösyvyyden $a$ neliöjuureen. Siksi tämä on valittu satunnaismuuttujaksi kirjoittajan menetelmässä. Yhteensopivuuden vuoksi näin on toimittava myös pinnankarheuden kohdalla. Siksi lopulliseksi satunnaismuuttujaksi analyysissä tulee $R=\sqrt{R_{z} / 3}$. Tämän muuttujan oletetaan noudattavan log-normaalijakaumaa. Jakauman parametrit iteroidaan niin, että sen keskiarvo ja hajonta ovat samat kuin pinnankarheusmittauksissa saadut. Esimerkki saaduista tiheysjakaumista on esitetty kuvassa 4. 


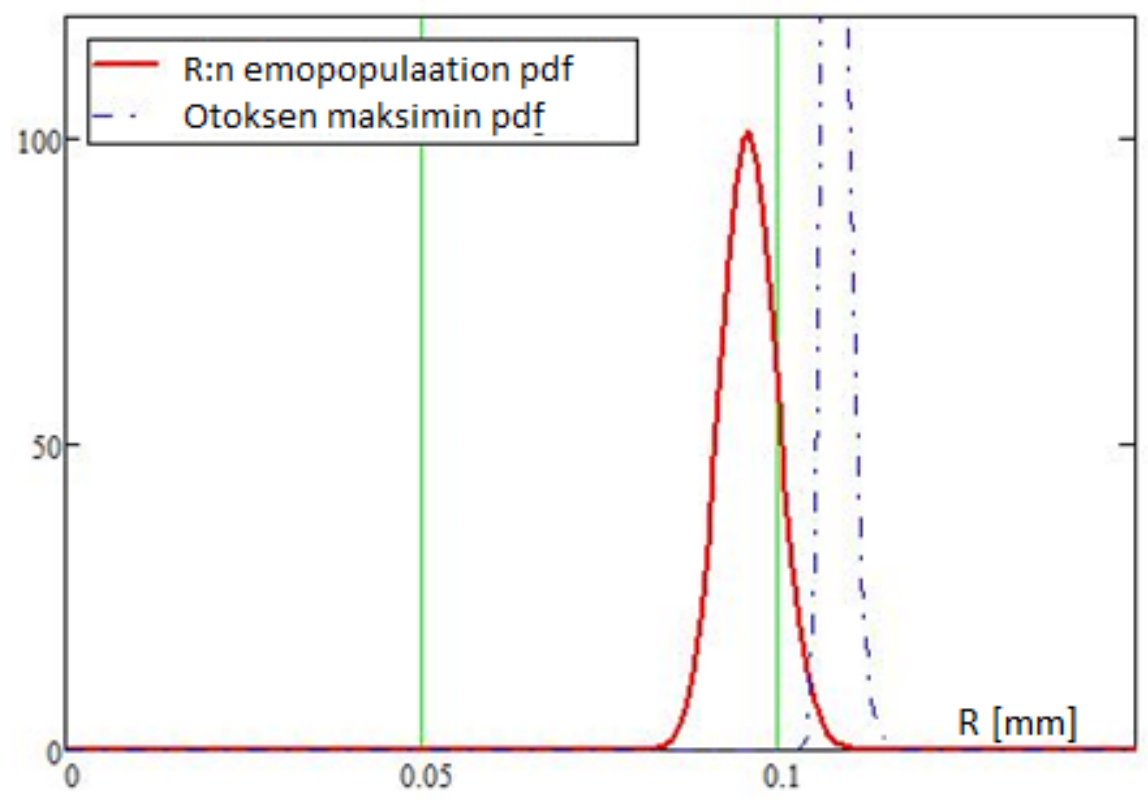

Kuva 4. Pinnankarheuden tiheysjakaumat alueella 2.

\section{Testitulokset}

Pinnankarheuden vaikutusta testataan Böhmin tuloksiin sauvalle X1 [14]. Se on sylinterin muotoinen sauva, halkaisijaltaan $7 \mathrm{~mm}$ ja sylinterimäisen osan pituus $16 \mathrm{~mm}$. Materiaali on nuorrutusteräs 30CrNiMo8. Väsymistestaus on suoritettu vetopuristuskuormalla $(R=-1)$. Tilastollinen analyysi on tehty viitteessä [1]. Saatu väsymisraja on $468 \mathrm{MPa}$ ja standardipoikkeama 21,5 MPa. Kun nämä muunnetaan särönsyvyyksiksi, saadaan seuraavat arvot: ydintyneen särönsyvyyden neliöjuuren keskiarvo $\sqrt{ } a=0,311 \sqrt{ } \mathrm{mm}$, hajonta $0,015 \sqrt{ } \mathrm{mm}$. Nämä arvot on saatu kaavasta (7) oletetulla kynnysarvolla $\Delta K_{\text {Ith }}=6 \mathrm{MPa} \sqrt{\mathrm{m}}$. Lognormaalijakauman parametreiksi saatiin: hajontaparametri $\alpha=0.149$, sijaintiparametri $\gamma=-1.70$. Otoskoon $n$ arvio laskettiin olettamalla kymmenen säröä per ulkopinnan $\mathrm{mm}^{2}$. Tästä saadaan $n=3520$.

Olettamalla, että teräkselle E470 saadut pinnankarheuden tilastolliset arvot pätevät myös teräkselle 30CrNiMo8, pinnankarheuden ja ydintyneen särön summajakauma saadaan kaavasta (8). Kokonaissärönsyvyydelle lasketaan estimaatti ja muunnetaan väsymislujuudeksi kaavan (6) avulla. Pinnanlaadun kerroin $k_{s f}$ saadaan kiillotetun koesauvan ja saadun väsymisrajan suhteena. Kaikki tulokset on esitetty taulukossa 5.

Esimerkki kokonaissärösyvyyden tiheysjakaumasta ja otoksen maksimin jakaumasta nähdään kuvassa 5 (koneistettu alue 2). 


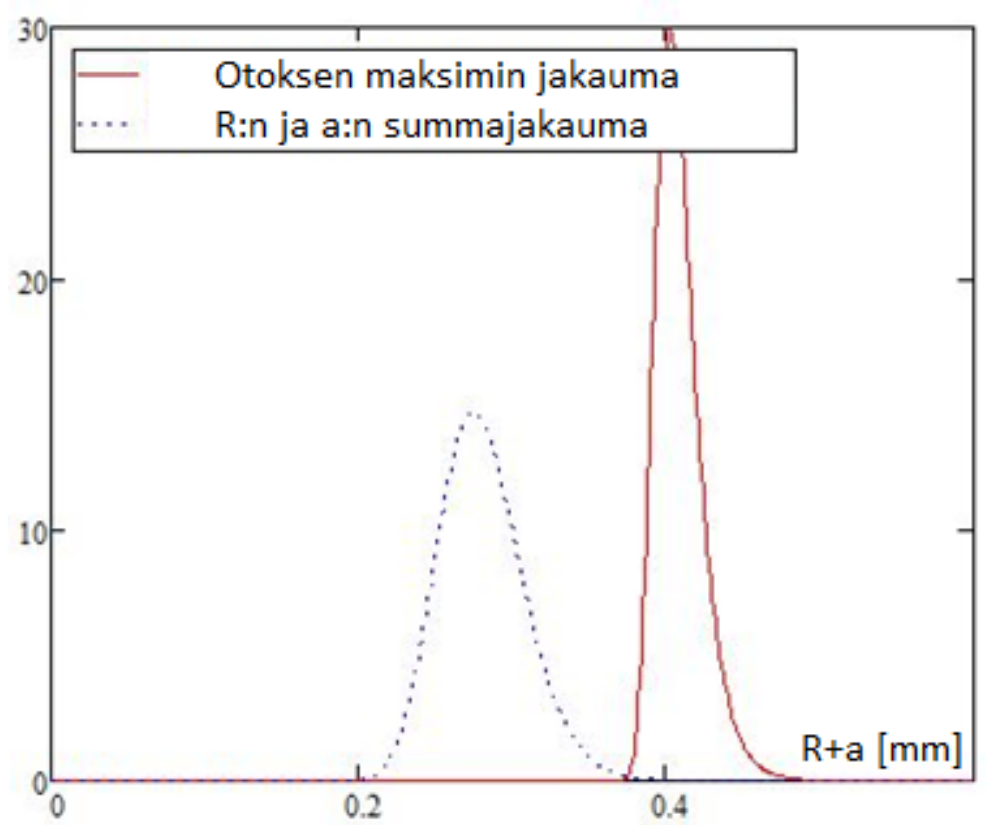

Kuva 5. Esimerkki pinnankarheuden ja ydintyneen särön summajakaumasta.

Taulukko 5. Lasketut tulokset Böhmin koekappaleelle X1

\begin{tabular}{ccccccc}
\hline $\begin{array}{c}\text { Koneistettu } \\
\text { alue nro }\end{array}$ & $\begin{array}{c}R_{\text {mean }} \\
\mu \mathrm{m}\end{array}$ & $\alpha$ & $\gamma$ & $\begin{array}{c}\sqrt{a_{\text {tot }}} \\
\sqrt{\mathrm{mm}}\end{array}$ & $\begin{array}{c}\Delta \sigma_{\mathrm{R}, \mathrm{a}+\mathrm{R}} \\
\mathrm{MPa}\end{array}$ & $k_{\mathrm{sf}}$ \\
\hline- & $\sim 0$ & 0,149 & $-1,70$ & 0,311 & 468 & 1 \\
1 & 7,6 & 0,280 & $-3,90$ & 0,335 & 435 & 0,93 \\
2 & 35,0 & 0,041 & $-2,345$ & 0,409 & 356 & 0,76 \\
3 & 51,3 & 0,040 & $-2,145$ & 0,430 & 339 & 0,73 \\
\hline
\end{tabular}

Ensimmäisellä rivillä ovat kiillotetun koesauvan arvot. $R_{\text {mean }}$ on mittauksien perusteella laskettu pinnankarheuden satunnaismuuttujan keskiarvo, $\sqrt{ } a_{\text {tot }}$ pinnankarheuden ja ydintyneen särön tilastollinen summa sekä $\Delta \sigma_{\mathrm{R}, \mathrm{a}+\mathrm{R}}$ väsymisrajan estimaatti pinnankarheus huomioon otettuna.

Toinen analyysi tehtiin perustuen viitteessä [20] julkaistuihin tuloksiin. Teräkselle S25C on annettu seuraavat arvot: murtolujuus $506 \mathrm{MPa}$, väsymisraja $10^{7}$ kuormanvaihdon kohdalla $259 \mathrm{MPa}$, variaatiokerroin 1,7 \%. Koekappale on sylinterin muotoinen halkaisijaltaan $8 \mathrm{~mm}$. Pituutta ei ole valitettavasti ilmoitettu. Otoskoko arvioitiin olettaen koestuspituudeksi $20 \mathrm{~mm}$. Silloin saadaan alkusäröjen otoskooksi $n=$ 5030. Laskentatulokset on ilmoitettu taulukossa 6 alla. 
Taulukko 6. Lasketut tulokset materiaalille S25C

\begin{tabular}{ccccccc}
\hline $\begin{array}{c}\text { Koneistettu } \\
\text { alue nro }\end{array}$ & $\begin{array}{c}R_{\text {mean }} \\
\mu \mathrm{m}\end{array}$ & $\alpha$ & $\gamma$ & $\begin{array}{c}\sqrt{a_{\text {tot }}} \\
\sqrt{\mathrm{mm}}\end{array}$ & $\begin{array}{c}\Delta \sigma_{\mathrm{R}, \mathrm{a}+\mathrm{R}} \\
\mathrm{MPa}\end{array}$ & $k_{\mathrm{sf}}$ \\
\hline- & $\sim 0$ & 0,053 & $-0,77$ & 0,562 & 259 & 1 \\
1 & 7,6 & 0,280 & $-3,90$ & 0,618 & 249 & 0.96 \\
2 & 35,0 & 0,041 & $-2,345$ & 0,659 & 221 & 0,85 \\
3 & 51,3 & 0,040 & $-2,145$ & 0,680 & 214 & 0,83 \\
\hline
\end{tabular}

Saatuja tuloksia on havainnollistettu kuvassa 6 alla. Kuvaan on piirretty kaksi suunnittelukäyrää viitteestä [5] ja vastaavat koepisteet. Pystyakselilla on pinnanlaadun vaikutuskerroin. Saadut tulokset Böhmin koekappaleelle X1 $\left(f_{u}=794 \mathrm{MPa}\right)$ on esitetty symbolilla $\mathrm{x}$ ja materiaalille S25C $\left(\left(f_{u}=506 \mathrm{MPa}\right)\right.$ symbolilla + .

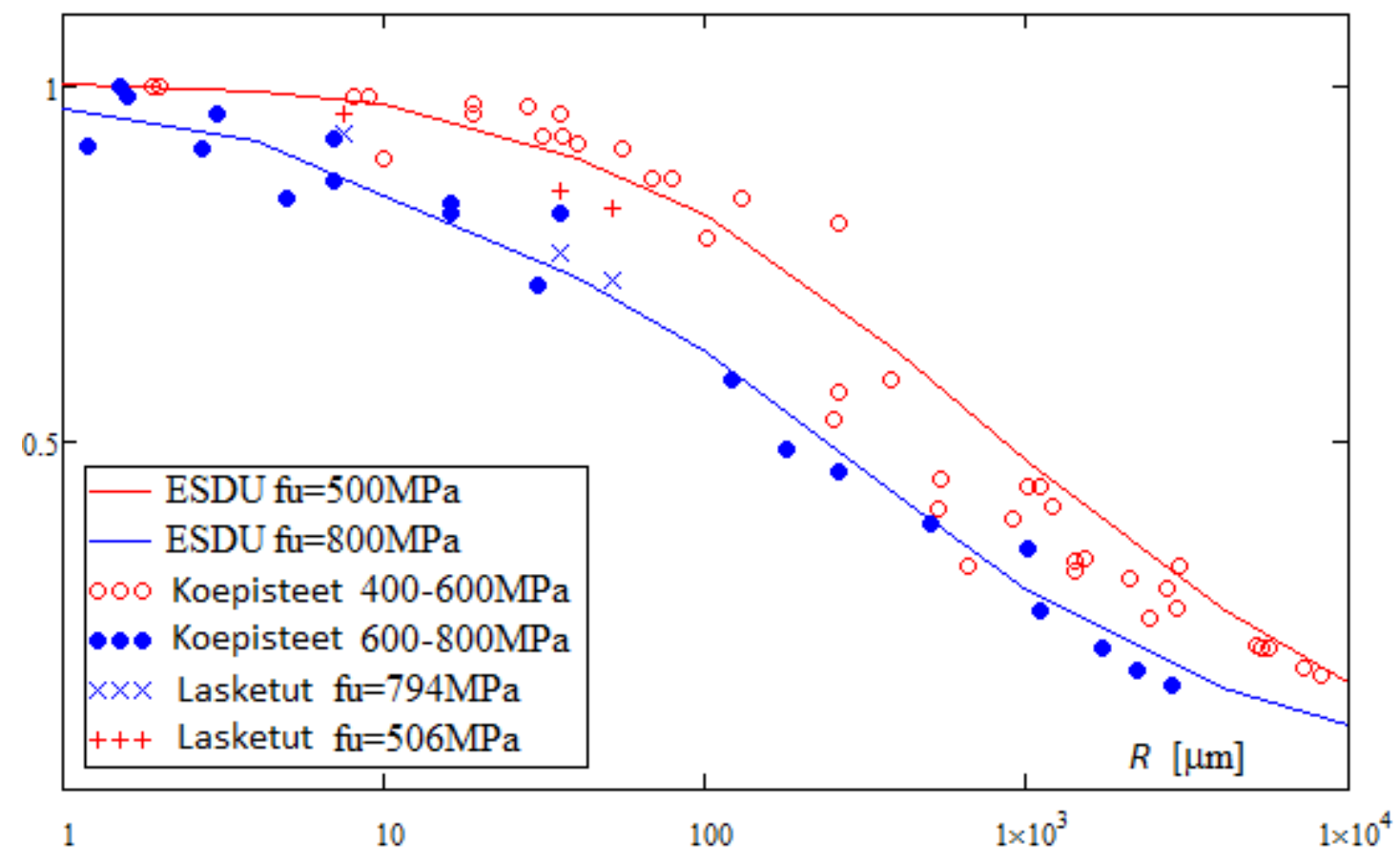

Kuva 6. Pinnanlaadun vaikutuskerroin pinnankarheuden $R$ funktiona. Osakopio ESDUn pinnankarheuden suunnittelukäyrästöstä [5] sekä lasketut estimaatit.

\section{Tulosten arviointi}

Nykyiset väsymismitoituksen alan käsikirjat tarjoavat vain yhden tavan arvioida pinnankarheuden vaikutus: erilaiset kokemusperäiset suunnittelukäyrästöt. Nämä ovat hyvin epätarkkoja eivätkä ota kaikkia tarpeellisia tekijöitä huomioon. ESDUn suunnittelukäyrästö on ainoita, missä on näytetty käyrästön pohjana olevat koepisteet. Kuvasta 6 voidaan todeta, että hajonta koepisteissä on erittäin suuri.

Pinnanlaadun kertoimet on määritetty pienillä koesauvoilla. Ei ole tietoa kuinka hyvin nämä pätevät todellisille koneenosille. Tätäkin seikkaa on mahdollista simuloida kirjoittajan suunnittelumenetelmällä. Yllä kuvattu laskentaprosessi toistettiin 
suuremmille otoksille. Kohdekappaleen X1 kokoa (eli jännityspinta-alaa) suurennettiin kertoimilla 10, 100 ja 1000. Analyysin tuloksia on havainnollistettu kuvassa 7. Nähdään, että pinnankarheuden vaikutus loivasti pienenee kappaleen koon kasvaessa. Tämä ei kuitenkaan ole yleinen trendi. Sama analyysi materiaalille S25C osoittaa päinvastaista suuntaa. Ilmeisesti tulos riippuu ydintyneen alkusärön sekä pinnankarheuden hajontojen suhteesta. Väsymislujuuden hajonta S25C:n tapauksessa on hyvin pieni, noin kolmasosa Böhmin testien hajonnasta.

Erilaiset koneistusmenetelmät ja koneistusparametrit tuottavat erilaiset tilastolliset pinnankarheusominaisuudet. Toisin kuin nykyisin käytössä olevilla keinolla, esitetty menetelmä antaa mahdollisuuden ottaa ne huomioon. Samalla voidaan ottaa huomioon kohdekomponentin koon vaikutus. Kuten viitteissä [1] ja [14] on näytetty, materiaalin väsymisraja alenee kappaleen koon kasvaessa. Muutos on suurinta pienillä sauvoilla ja loivenee kappaleen koon kasvaessa. Yksi ESDUn kokeiden hajontaan vaikuttava tekijä todennäköisesti on, että kokeita on tehty erikokoisilla ja erimuotoisilla koesauvoilla. Kokeissa on silloin mukana tilastollista koon vaihtelua, minkä takia tulokset eivät ole keskenään täysin vertailukelpoisia.

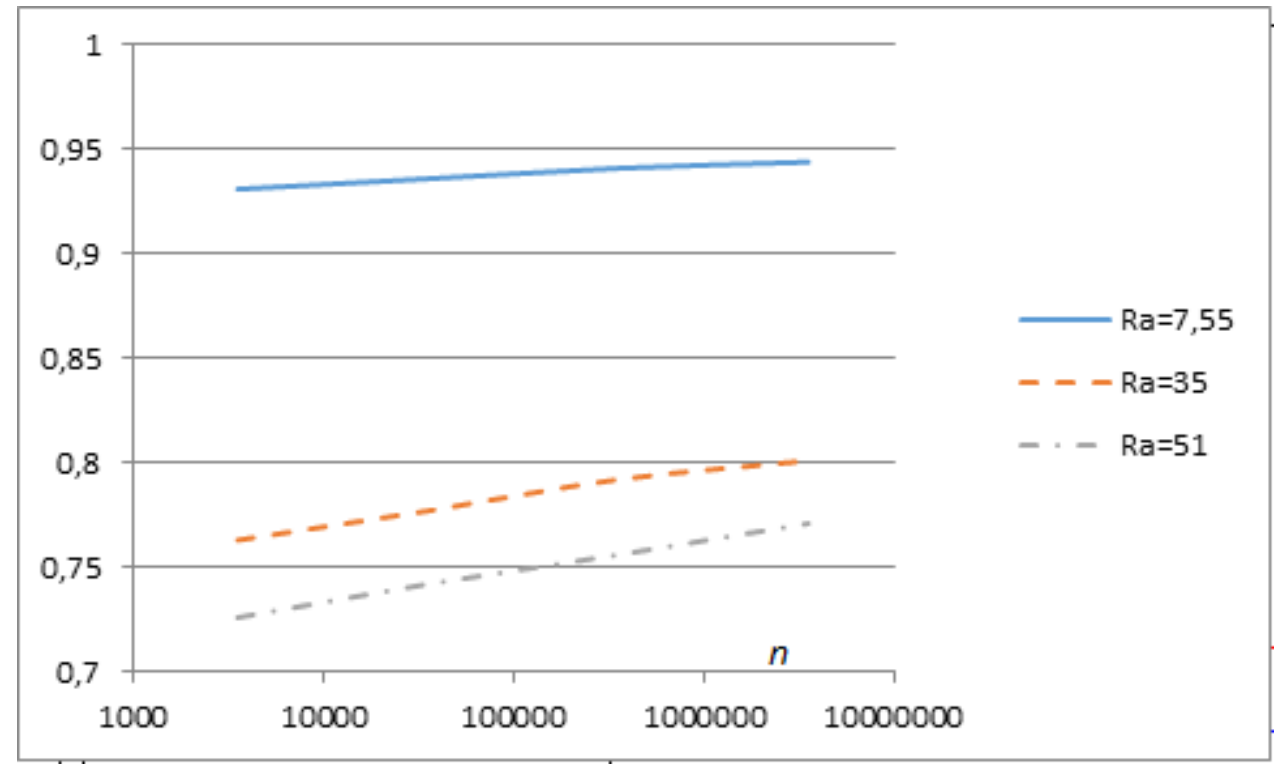

Kuva 7. Pinnanlaadun vaikutuskertoimen riippuvuus kappaleen koosta.

\section{Johtopäätökset pinnankarheuden korjauskertoimen arvioinnista}

Alan kirjallisuudesta löytyvät pinnankarheuden vaikutuskertoimet ovat hyvin epätarkkoja. Ne eivät anna mahdollisuutta ottaa huomioon eri koneistustapoja sekä koneistusparametrien vaikutusta.

Pinnankarheuden profiili yhdistyy ydintyviin alkusäröihin tilastollisesti. Nykyisin käytettävissä olevista menetelmistä vain kirjoittajan kehittämä alkusäröjakaumiin perustuva malli mahdollistaa tilastollisen analyysin.

Pinnanlaadun korjauskerroin ei ole vakio, vaan riippuu ainakin mitoitettavan kappaleen koosta ja alkusäröjakauman sekä pinnankarheuden hajontojen suuruuksien suhteesta. 


\section{Johtopäätökset}

Myös silloin kun kaksi koneenosaa on valmistettu samasta materiaalista, niiden väsymisominaisuudet voivat erota huomattavasti teknologisista tekijöistä johtuen. Tästä seuraa muun muassa se, että kirjallisuudesta löytyviin väsymiskokeiden tuloksiin tulee suhtautua varovaisuudella. Väsymislujuuden laskenta-arvot tulisi aina määrittää koekappaleilla, jotka ovat ominaisuuksiltaan riittävän lähellä kohdekappaletta. Erityisesti materiaalinpaksuuden vaikutus tulisi arvioida huolellisesti. Aina kun on mahdollista, lähtötiedot tulisi määrittää kokeilla, joissa ainespaksuus ja muut ominaisuudet vastaavat tarkasteltavaa komponenttia. Muussa tapauksessa väsymismitoituksessa tulee soveltaa sopivia korjaustapoja.

Ainepaksuuden muutos vaikuttaa sekä väsymislujuuden keskiarvoon että sen hajontaan. Keskiarvon muutos voidaan arvioida kohtuullisella tarkkuudella staattisen lujuuden muutoksen avulla. Materiaalinpaksuuden kasvaminen pyrkii suurentamaan väsymislujuuden hajontaa. Toisaalta taas hajonta pienenee tilastollisen koon vaikutuksen johdosta, koska kappaleen jännityspinta-ala kasvaa. Nämä kaksi pitää saada erotetuksi toisistaan väsymiskokeilla ja tilastollisella analyysillä.

Olemassa olevat pinnankarheuden vaikutuksen arviointitavat eivät ole ollenkaan tyydyttäviä. Tilastollinen analysointi on tarpeen riittävän käsityksen saamiseksi. Tämä koskee sekä pinnankarheuden tilastollisia ominaisuuksia sekä sen yhdistämistapaa väsymislujuuden ennustamiseen. Nykyisin käytössä olevat väsymismitoitusmenetelmät eivät tue tilastollista lähestymistapaa, pois lukien kirjoittajan kehittämä alkusäröjen jakaumiin perustuva tapa. Viime mainitulla on mahdollista simuloida erilaisten pinnankarheuden profiilien yhdistymistä ydintyneisiin alkusäröihin ja sitä kautta väsymislujuuteen.

\section{Kiitosmaininnat}

Suuret kiitokset Vaasan yliopiston lehtori Bernd Papelle avusta kahden satunnaismuuttujan yhdistämistä koskevassa tilastollisessa laskennassa.

\section{Viitteet}

[1] Makkonen M. Size effect and notch size effect in metal fatigue. Thesis for the degree of Doctor of Science (Technology), Lappeenranta University of Technology. Acta Universitatis Lappeenrantaensis 83; 1999.

[2] Krä Chr. and Heckel K. Übertragung von Schwingfestigkeitswerten mit dem statistischen Grösseneinfluss. Mat.-wiss. u. Werkstofftechnik 20 No. 8, 255-261; 1989. https://doi.org/10.1002/mawe.19890200803

[3] Kloos K.H. Einfluss des Oberflächenzustandes und der Probengrösse auf die Schwingfestigkeitseigenschaften. VDI-Berichte No. 268, 63-76; 1976

[4] Sonsino C., Kaufmann H., and Grubišić V. Transferability of material data for the example of a randomly loaded forged truck stun axle. SAE Technical Paper 970708; 1997

[5] ESDU 74027.The effect of surface roughness on the fatigue limit of steels (at zero mean stress). The Royal Aeronautical Society Institution of Mechanical Engineers. ESDU International plc, 27 Corsham Street, London N1 6UA; 1974 
[6] Lai J., Huang H. and Buising W. Effects of microstructure and surface roughness on the fatigue strength of high-strength steels. Procedia Structural Integrity, Volume 2, 12131220; Elsevier 2016. https://doi.org/10.1016/j.prostr.2016.06.155

[7] Arola D. and Williams C.L. Estimating the fatigue stress concentration factor of machined surfaces. Int J Fatigue 2002; 24: 923-930. https://doi.org/10.1016/S0142-1123(02)000129

[8] Murakami Y. Inclusion Rating by Statistics of Extreme Values and Its Application to Fatigue Strength Prediction and Quality Control of Materials. Journal of Research of the National Institute of Standards and Technology, Volume 99, Number 4, July-August; 1994. https://doi.org/10.6028/jres.099.032

[9] M.Goto, H.Nisitani. Relation between scatter characteristics of fatigue life and crack growth behaviour of a heat treated carbon steel. Short Fatigue Cracks, ESIS 13 (Edited by K.J.Miller and E.R. de los Rios), Mechanical Engineering Publications, London, pp. 485501; 1992

[10] Roiko A. The Extreme Value Analysis of Non-metallic Inclusions and Their Effect on the fatigue Limit of Steel. Master thesis, Aalto University, 2010

[11] Murakami Y. and Endo M. Effects of defects, inclusions and inhomogeneities on fatigue strength. Int J Fatigue 1994; 16: 163-182. https://doi.org/10.1016/0142-1123(94)90001-9

[12] Buch A. Fatigue strength calculation. Trans. Tech., Switzerland-Germany-U.K.-U.S.A; 1988

[13] Magin W. Untersuchung des geometrischen Grösseneinflusses bei umlaufbiegebeanspruchung unter besonderer berücksichtigung technologischer einflüsse. Dissertation, Technische Hochschule Darmstadt; 1981

[14] Böhm J. Zur Vorhersage von Dauerschwingfestigkeiten ungekerbter und gekerbter Bauteile unter Berücksichtigung des statististischen Grösseneinflüsses. Dissertation, Technische Universität München; 1979

[15] Makkonen M. Statistical size effect in the fatigue limit of steel. Int J Fatigue 2001; 23:395-402. https://doi.org/10.1016/S0142-1123(01)00003-2

[16] Makkonen M. Notch size effects in the fatigue limit of steel. Int J Fatigue 2003; 25:17-26. https://doi.org/10.1016/S0142-1123(02)00053-1

[17] Makkonen M. Practical tools for statistical fatigue design. Ping Tang and Jim Leor Zhang (Ed.) Fatigue Crack Growth. Mechanisms, Behaviour and Analysis: 97-126, Nova Science Publishers, New York, 2012

[18] Weibull W. A Statistical Representation of Fatigue Failures in Solids. Transactions of the Royal Institute of Technology, Stockholm, Sweden, Number 27; 1949

[19] Ross S.R. Introduction to probability Models, 10th edition. Elsevier, USA; 2010.

[20] Nishijima, S. Statistical Fatigue Properties of Some Heat-Treated Steels for Machine Structural Use. Statistical Analysis of Fatigue data. ASTM STP 744. R. E. Little and J. Ekvall, Eds., ASTM, 1981, pp. 5-88.

Matti Makkonen

Vaasan Ammattikorkeakoulu

Wolffintie 30, 65200 Vaasa

matti.makkonen@outlook.com 